\title{
Effect of microbial inoculants on the chemical composition and aerobic stability of Tanzania guinea grass silages
}

\author{
V.H. Bumbieris Junior ${ }^{1}$, E.H. Horst ${ }^{2 \#}$, V.A.P. Guimarães ${ }^{3}$, F.L. Massaro Junior ${ }^{2}$, G.J. Moraes ${ }^{4}$, \\ D.A.R. Meza ${ }^{5}$ \& S. Galbeiro ${ }^{1}$ \\ ${ }^{1}$ Department of Zootechnics, State University of Londrina, Londrina, Paraná, Brazil \\ ${ }^{2}$ Post-Graduate in Animal Science, State University of Londrina, Londrina, Paraná, Brazil \\ ${ }^{3}$ Paranaense Institute of Technical Assistance and Rural Extension, Alto Paraná, Paraná, Brazil \\ ${ }^{4}$ Center of Animal Science, Federal University of Mato Grosso do Sul, Campo Grande, Mato Grosso do Sul, Brazil \\ ${ }^{5}$ Department of Animal Science, State University of São Paulo "Júlio de Mesquita Filho", Jaboticabal, São Paulo, Brazil
}

(Submitted 3 July 2018, Accepted 25 November 2020, Published 15 January 2021)

\begin{abstract}
Copyright resides with the authors in terms of the Creative Commons Attribution 4.0 South African Licence.
See: http://creativecommons.org/licenses/by/4.0/za

Condition of use: The user may copy, distribute, transmit and adapt the work, but must recognise the authors and the South African Journal of Animal Science.
\end{abstract}

\begin{abstract}
The present study evaluated the effects of microbial inoculants on chemical changes and aerobic stability efficiency in Tanzania guinea grass silage. The treatments consisted of C: silage without inoculant; I: silage inoculated with Lactobacillus plantarum (CCT 0580) $8.0 \times 10^{9} \mathrm{CFU} \mathrm{g}^{-1}$, Bacillus subtilis (CCT 0089) $2.0 \times 10^{9} \mathrm{CFU} \mathrm{g}^{-1}$, and Pediococcus acidilactici (CCT 2553) $1.0 \times 10^{10} \mathrm{CFU} \mathrm{g}{ }^{-1}$, and L: silage inoculated with Lactobacillus plantarum (CCT 0580) $2.6 \times 10^{10} \mathrm{CFU} \mathrm{g}^{-1}$ and Pediococcus pentosaceus (CCT 7659) $2.6 \mathrm{x}$ $10^{10} \mathrm{CFU} \mathrm{g}{ }^{-1}$. The experimental design was completely randomized, with five replications. There were no treatment effects on the nutritional composition of the silages, but both inoculants were effective in reducing the $\mathrm{pH}$ of the silage to 4.80 and 4.83 for I and L, respectively, compared with 5.04 for C. Silage with $\mathrm{L}$ had a lower ammonia nitrogen $\left(\mathrm{N}_{-} \mathrm{NH}_{3}\right)$ content than the other silages $(9.83 \%)$. Despite the lower $\mathrm{pH}$ values, the use of inoculants did not reduce fungal and yeast counts or improve the aerobic stability of Tanzania guinea grass silages.
\end{abstract}

\footnotetext{
Keywords: aerobic deterioration, ammonia nitrogen, lactic bacteria, Panicum maximum, spoilage microorganisms

\#Corresponding author: egonhh@yahoo.com.br
}

\section{Introduction}

Cultivars of Panicum maximum Jacq. are characterized by accelerated growth and high potential for fresh matter production per unit area. Tanzania guinea grass is one of the most used Panicum cultivars in pasture formation and in the production of preserved feed. When harvested for silage production, its apex of nutritional quality coincides with the stage where forage has low dry matter (DM) and soluble carbohydrates, and high buffer capacity (Zanine et al., 2018), which may impair fermentation and favour Clostridium (Santos et al., 2008). These characteristics affect the nutritional quality of the silage, and also the aerobic stability when the silo is opened (Santos et al., 2014).

The use of lactic acid bacteria as inoculants to minimize the deterioration of grass silage has been studied (Santos et al., 2008; Tabacco et al., 2009; Khota et al., 2016; Zanine et al., 2016). However, the results of these studies have been contradictory and inconclusive. It is believed that differences among the strains of bacteria that were used contributed to the disparate effects (Dong et al., 2020). Ávila et al. (2009) described improvements in the fermentation profile and reduction of fungi concentration in Mombaça guinea grass silage that was inoculated with Lactobacillus buchneri. Santos et al. (2008) observed the nutritional superiority of inoculated Tanzania guinea grass silage compared with control silage. However, Paziani et al. (2006) found no positive effects from inoculation in Tanzania guinea grass silage. In most of these studies, the inoculants contained strains of Lactobacillus buchneri and Lactobacillus plantarum, with little insight into other strains with conservative potential.

Species of the genus Bacillus have known ability to produce antimicrobial substances, including antibiotics. However, few studies have evaluated them as possible agents for improvement of forage 
fermentation. Although not classified as lactic bacteria, Bacillus subtilis has the potential to produce acetic acid. The use of Bacillus was observed to have beneficial effects on nutritional quality and aerobic stability in corn silage (Basso et al., 2012). Bacillus subtilis can facilitate aerobic metabolism in the initial phase of fermentation when there is residual oxygen and yeasts develop exponentially. Bacillus subtilis may prevent the development of yeasts by producing anti-fungal substances or by competing for substrate. In a review, Muck et al. (2018) reported that inoculants with Bacillus improved aerobic stability of silages by controlling the growth of yeasts.

Effective production of lactic acid is important for rapid $\mathrm{pH}$ drop, reduced protein degradation, and reduced growth of undesirable microorganisms (Ávila et al., 2009, Konca et al., 2016). Homo-fermentative strains, such as Pediococcus acidilactici and Pediococcus pentosaceus, can be used for process efficiency (Konca et al., 2016). Kleinschmit and Kung Jr. (2006). However, these results raise awareness of the importance of working with associations of microorganisms and further studies are needed to evaluate the most appropriate combinations. Thus, the goal of this study was to evaluate inoculants with mixtures of microbial strains for effects on the nutritional value and aerobic stability of Tanzania guinea grass silage.

\section{Material and Methods}

Tanzania guinea grass (Panicum maximum Jacq. Tanzania) was grown at the State University of Londrina, Londrina, State of Paraná, located at coordinates $23^{\circ} 23^{\prime} \mathrm{S}$ and $51^{\circ} 11^{\prime} \mathrm{W}$ at an altitude of $566 \mathrm{~m}$. After 80 days of regrowth, the material was harvested, immediately ground in a stationary mill, the additives applied and ensiled. The additives were diluted in non-chlorinated water and homogeneously sprayed onto the ground material before being ensiled. The treatments evaluated were: $(C)$ control silage with water applied in the same proportion as the other silages; (I) silage with an inoculum of Lactobacillus plantarum [CCT 0580] 8.0 $\times 10^{9} \mathrm{CFU} \mathrm{g}^{-1}$, Bacillus subtilis [CCT 0089] $2.0 \times 10^{9} \mathrm{CFU} \mathrm{g}^{-1}$, and Pediococcus acidilactici [CCT 2553] $1.0 \times 10^{10} \mathrm{CFU} \mathrm{g}^{-1}$, and (L) silage with an inoculum of Lactobacillus plantarum [CCT 0580] $2.6 \times 10^{10} \mathrm{CFU} \mathrm{g}^{-1}$ and Pediococcus pentosaceus [CCT 7659] $2.6 \times 10^{10} \mathrm{CFU} \mathrm{g}^{-1}$.

Fifteen 18 liter polyethylene buckets closed with a plastic cap and sealed with adhesive tape were used as experimental silos. The silage had an average particle size of $31.98 \mathrm{~mm}$ and was packed to an average density of $497.7 \mathrm{~kg}$ fresh matter $\mathrm{m}^{-3}$ as described by Lammers et al. (1996) (Table 1).

Table 1 Particle retention on sieves with different mesh sizes, average particle size and density of tanzania guinea grass silages with different microbial inoculants

\begin{tabular}{|c|c|c|c|c|c|c|}
\hline \multirow{2}{*}{ Silages } & \multicolumn{4}{|c|}{ Particles retained on the sieve, $\%$} & \multirow{2}{*}{ Average particle size, $\mathrm{mm}$} & \multirow{2}{*}{ Density, $\mathrm{kg} \mathrm{FM} \mathrm{m}^{-3}$} \\
\hline & $19 \mathrm{~mm}$ & $8 \mathrm{~mm}$ & $4 \mathrm{~mm}$ & $0 \mathrm{~mm}$ & & \\
\hline C & 89.2 & 7.2 & 3.8 & 0.0 & 31.15 & 485.1 \\
\hline 1 & 94.0 & 4.0 & 1.8 & 0.0 & 33.34 & 507.0 \\
\hline L & 89.8 & 6.6 & 3.4 & 0.0 & 31.45 & 500.9 \\
\hline
\end{tabular}

C: silage treated with water, I: silage treated with Lactobacillus plantarum, Bacillus subtilis and Pediococcus acidilactici, L: silage treated with Lactobacillus plantarum and Pediococcus pentosaceus

After 60 days, the silos were opened, and $10 \mathrm{~cm}$ portions from the top and bottom were discarded. Samples were collected immediately for fungi and yeast counts in which $25 \mathrm{~g}$ fresh silage was diluted in 225 $\mathrm{mL}$ deionized water to prepare the aqueous extract. Aliquots of $1 \mathrm{~mL}$ of each dilution were pipetted into sterile Petri dishes $(100 \times 20 \mathrm{~mm})$, which were prepared in duplicate. Fifteen $\mathrm{mL}$ dextrose potato agar was added to each dish. It had previously been melted, cooled to $45^{\circ} \mathrm{C}$ and acidified to $\mathrm{pH} 3.5 \pm 0.1$ with $10 \%$ tartaric acid. The mixture was solidified at room temperature and incubated inverted at $25^{\circ} \mathrm{C}$ for 72 hours for the yeast count, and 120 hours for the fungal count (Downes \& Ito, 2001). The number of microorganisms was enumerated as colony forming units (CFU) and $\log _{10}$ transformed. This procedure was repeated after the silages had been exposed to air for seven days.

Silo temperature was measured daily at $08 \mathrm{~h} 00$ and $16 \mathrm{~h} 00$ with a digital immersion thermometer 10 $\mathrm{cm}$ below the surface, without stirring. Ambient temperature was also recorded at these times and $\mathrm{pH}$ was measured (Cherney \& Cherney, 2003). On the first and last days, samples were taken to determine ammonia nitrogen $\left(\mathrm{NH}_{3}-\mathrm{N}\right.$ Total $\left.\mathrm{N}^{-1}\right)$, dry matter (DM), crude protein (CP), acid detergent fibre (ADF), neutral detergent fibre (NDF), and ashes, according to AOAC (1995). 
The experiment was a completely randomized design, with five replications. The data were tested with the Shapiro-Wilk and Bartlett tests to check the assumptions of normality and homogeneity of variance, respectively. Those response variables that were recorded one time on an experimental unit subjected to one-way analysis of variance using SAS (SAS Institute Inc., Cary, North Carolina, USA). Treatment effects were tested at the $5 \%$ level of probability and then with Tukey's test for comparison of means. For the variables that were recorded daily, a split plot in time model was used for the statistical analysis. For the study of temperature and $\mathrm{pH}$ over time, Box-plot charts were used to allow visualization of dispersion, asymmetry and discrepant data.

\section{Results and Discussion}

No differences were detected in the nutritional value of the silages (Table 2). Both inoculants were effective in reducing the $\mathrm{pH}$ relative to the control silage. Sufficient concentrations of soluble carbohydrates are required as the fuel for lactic acid bacteria (Tomaz et al., 2018; Dong et al., 2020). When this condition is met, the bacteria present in the inoculants produce lactic acid and acetic acid, resulting in lowered $\mathrm{pH}$ (Holzer et al., 2003). As a consequence, microbial metabolic activity inside the silo is reduced and the forage can be preserved for longer periods (McDonald et al., 1991). High pH conditions also favour development of Clostridium bacteria, which can take advantage of aerobic conditions after opening the silo to convert proteins into $\mathrm{NH}_{3}-\mathrm{N}$ (Bumbieris Junior et al., 2017; Zanine et al., 2018). Controlling Clostridium bacteria in silages with inoculants can be difficult in humid conditions, and dry matter may be lost as a result (Tomaz et al., 2018).

Proteolytic activity is consistently related to the $\mathrm{NH}_{3}-\mathrm{N}$ contents of silage. However, in the present study only $\mathrm{L}$ reduced $\mathrm{NH}_{3}-\mathrm{N}$ compared with $\mathrm{C}$. Homolactic and heterolactic bacteria promote a faster rate of fermentation, providing less proteolysis (Muck, 2010). Bacillus subtilis present in I might have reduced the rate of fermentation, resulting in the similarity of this silage to $\mathrm{C}$. Lower $\mathrm{NH}_{3}-\mathrm{N}$ was seen in this study than in Tomaz et al. (2018), but the level was similar to Zanine et al. (2018). It should be noted that $\mathrm{NH}_{3}-\mathrm{N}$ contents above $10 \%$ of total $\mathrm{N}$ are considered detrimental to the nutritional and sanitary qualities of the silages.

Table 2 Chemical composition of Tanzania guinea grass silages with various microbial inoculants

\begin{tabular}{lrrrr}
\hline \multirow{2}{*}{ Variables } & \multicolumn{3}{c}{ Silages } & \multirow{2}{*}{$P$-value } \\
\cline { 2 - 4 } & \multicolumn{1}{c}{$\mathrm{C}$} & $\mathrm{I}$ & $\mathrm{L}$ \\
\hline & $29.13 \pm 0.59$ & $29.68 \pm 0.44$ & $29.32 \pm 0.51$ & 0.6266 \\
Dry matter, \% FM & $8.26 \pm 0.34$ & $8.34 \pm 0.10$ & $8.62 \pm 0.12$ & 0.1900 \\
Crude protein, \% DM & $67.64 \pm 0.74$ & $67.43 \pm 0.80$ & $67.25 \pm 0.58$ & 0.3019 \\
Neutral detergent fibre, \% DM & $42.46 \pm 1.37$ & $42.39 \pm 1.62$ & $43.76 \pm 1.00$ & 0.1232 \\
Acid detergent fibre, \% DM & $12.56 \pm 0.16$ & $12.98 \pm 0.20$ & $12.78 \pm 0.20$ & 0.6609 \\
Ash, \% DM & $5.04^{\mathrm{a}} \pm 0.02$ & $4.80^{\mathrm{b}} \pm 0.03$ & $4.83^{\mathrm{b}} \pm 0.04$ & $<0.0001$ \\
$\mathrm{pH}$ & $11.08^{\mathrm{a}} \pm 0.94$ & $11.06^{\mathrm{a}} \pm 0.58$ & $9.83^{\mathrm{b}} \pm 0.93$ & $<0.0001$
\end{tabular}

C: silage treated with water, I: silage treated with Lactobacillus plantarum, Bacillus subtilis and Pediococcus Acidilactici, $\mathrm{L}$ : silage treated with Lactobacillus plantarum and Pediococcus pentosaceus, FM: fresh matter, DM: dry matter, NH3-N: ammonia nitrogen $(\mathrm{N})$

${ }_{a, b}$ Within a row, means with a common superscript were not different with probability $P=0.05$

The yeast and fungal counts increased in time since opening the silos, but were similar among the treatments (Table 3). Tabacco et al. (2009) also detected no difference in fungal and yeast counts in corn and sorghum silages, irrespective of their having been inoculated with Lactobacillus plantarum. Basso et al. (2012) reported that inoculation with Bacillus subtilis at $5.0 \times 10^{5} \mathrm{CFU} \mathrm{g}^{-1}$ controlled the growth of aerobic spoilage microorganisms and increased aerobic stability of in corn silage at a pH of 3.74 . Growth of fungi and yeasts occurs mainly at pH higher than 4.5 (Muck, 2010), and in the present study, the high pH of Tanzania guinea grass silages may have favoured the accelerated development of these microorganisms, thus compromising silage preservation. In short, the present results corroborate much of the literature on the development of spoilage microorganisms under aerobic conditions in silages. In addition, the present study 
is the first evaluation of Bacillus subtilis as an inoculant in Tanzania guinea grass silage, and additional studies are needed of its mechanism of action during the fermentation process.

Table 3 Fungal and yeast counts (log CFU g ${ }^{-1}$ ) in Tanzania guinea grass silages with various microbial inoculants on the first and seventh day after opening the silos

\begin{tabular}{lcccc}
\hline \multirow{2}{*}{ Variables } & \multicolumn{3}{c}{ Silages } & Mean \\
\cline { 2 - 4 } & $\mathrm{C}$ & $\mathrm{I}$ & $\mathrm{L}$ & \\
\hline Day 1, log CFU g & & & & \\
Day $7, \log \mathrm{CFU} \mathrm{g}^{-1}$ & 2.66 & 2.35 & 2.21 & $2.45^{\mathrm{B}}$ \\
& 5.20 & 5.89 & 5.75 & $5.70^{\mathrm{A}}$
\end{tabular}

CFU: colony-forming units; C: silage treated with water, I: silage treated with Lactobacillus plantarum, Bacillus subtilis and Pediococcus acidilactici, L: silage treated with Lactobacillus plantarum and Pediococcus pentosaceus

${ }_{A, B}$ Within a column, means with a common superscript were not different with probability $P=0.05$

In $C$ there was a quadratic effect $(P<0.05)$ on temperature with increasing days of exposure to air. However, the temperatures of $I$ and $L$ increased linearly over time after opening of silo. The increase in temperature over time is because of the enzymatic activity of the deleterious microorganisms that release energy (heat) during the process of nutrient degradation (Bumbieris Junior et al., 2017). This is different from what occurs normally in corn silages (Tomaz et al., 2018) and supports the concept that tropical grasses are more prone to deterioration by aerobic bacteria. This deterioration occurs because of the stability of the fermentation at $\mathrm{pH}$ above 4.5, high moisture content and absence of soluble carbohydrates. The difficulty in gaining thermal increase may also be related to the lower efficiency of aerobic bacteria in producing heat compared with yeasts and the greater energy requirement for heating in more moist environments.

Table 4 Regressions of Tanzania guinea grass silage temperature and $\mathrm{pH}$ on time after silo opening

\begin{tabular}{|c|c|c|c|c|}
\hline Silages & Regression equation & $R^{2}$ & $P$-value & $\mathrm{CV}, \%$ \\
\hline \multicolumn{5}{|c|}{ Temperature } \\
\hline C & $24.80+0.0075 x+0.0374 x^{2}$ & 0.7424 & $<0.0001$ & 1.86 \\
\hline I & $24.25+0.2925 x$ & 0.7140 & $<0.0001$ & 1.68 \\
\hline $\mathrm{L}$ & $24.10+0.3298 x$ & 0.8078 & $<0.0001$ & 1.66 \\
\hline \multicolumn{5}{|c|}{$\mathrm{pH}$} \\
\hline C & $5.06-0.0028 x+0.0087 x^{2}$ & 0.9080 & 0.0006 & 4.05 \\
\hline I & $4.72+0.1721 x-0.0134 x^{2}$ & 0.8170 & $<0.0001$ & 1.58 \\
\hline $\mathrm{L}$ & $4.77+0.1465 x-0.0115 x^{2}$ & 0.7845 & $<0.0001$ & 1.60 \\
\hline
\end{tabular}

C: silage treated with water, I: silage treated with Lactobacillus plantarum, Bacillus subtilis and Pediococcus acidilactici, L: silage treated with Lactobacillus plantarum and Pediococcus pentosaceus

The regression equation that represents the $\mathrm{pH}$ of $\mathrm{C}$ also differed from I and $\mathrm{L}$. For $\mathrm{C}$, the trend was increased at an increasing rate over time, whereas for $\mathrm{I}$ and $\mathrm{L}$ the trends in $\mathrm{pH}$ increased to maxima and decreased thereafter. Figures 1 and 2 help one to understand the temperature and $\mathrm{pH}$ in the hours after the silos were opened. 


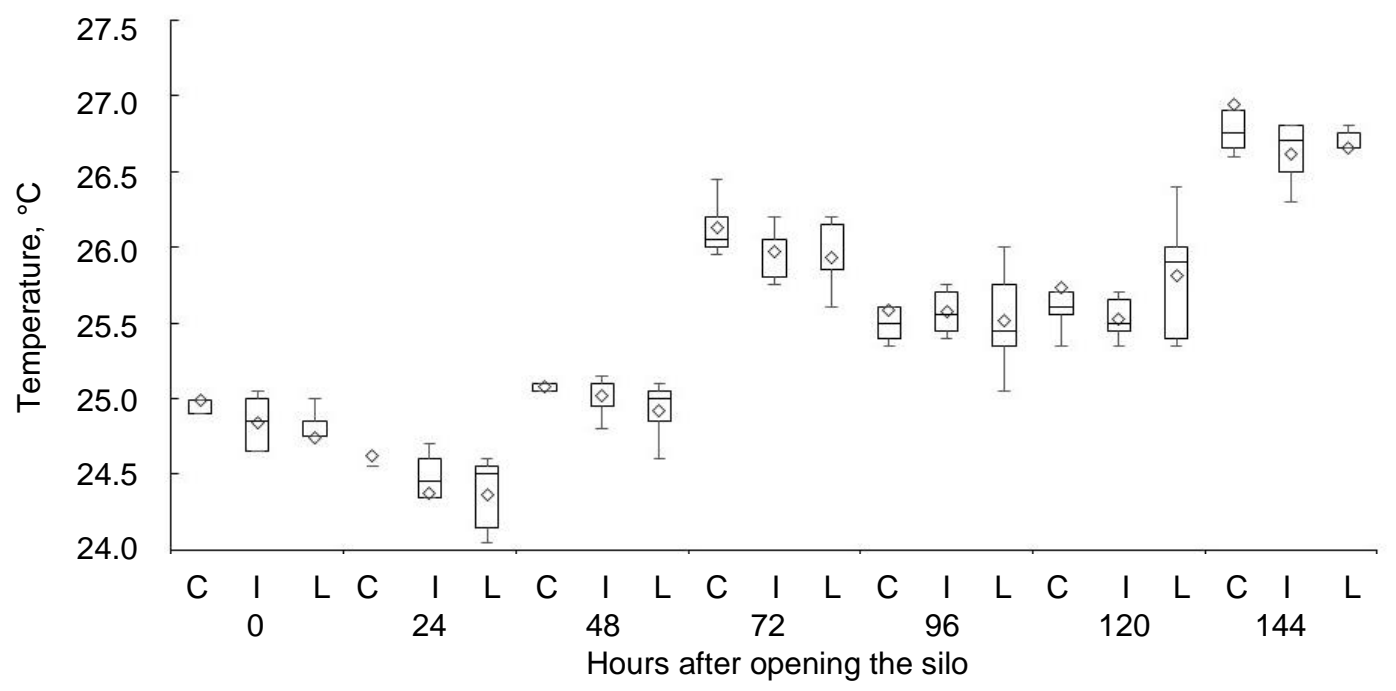

Figure 1 Mean temperature values of the silages over the hours of aerobic exposure C: silage treated with water, I: silage treated with Lactobacillus plantarum, Bacillus subtilis and Pediococcus acidilactici, L: silage treated with Lactobacillus plantarum and Pediococcus pentosaceus

The increase in temperature detected over the hours of aerobic exposure is generally observed in silages independent of the inoculant, forage species and evaluation methodologies. According to Adesogan (2009), higher environmental temperatures may cause growth of undesirable microorganisms in silages such as clostridium and enterobacteria. A similar effect can be inferred for $\mathrm{pH}$, confirming the change in nutritional value can be attributed to deleterious microorganisms. Yeasts are in the forefront of the timing and severity of these effects. Higher concentrations of lactic bacteria provide for a faster decline in $\mathrm{pH}$ of the ensiled mass, and reducing the time for yeast to develop prior to the transformation to an anaerobic environment after silo sealing (McDonald et al., 1991). This activity of yeasts does not resume when the silage is again exposed to air. It should be noted that both temperature and $\mathrm{pH}$ are related to the aerobic stability of the silage (Table 5).

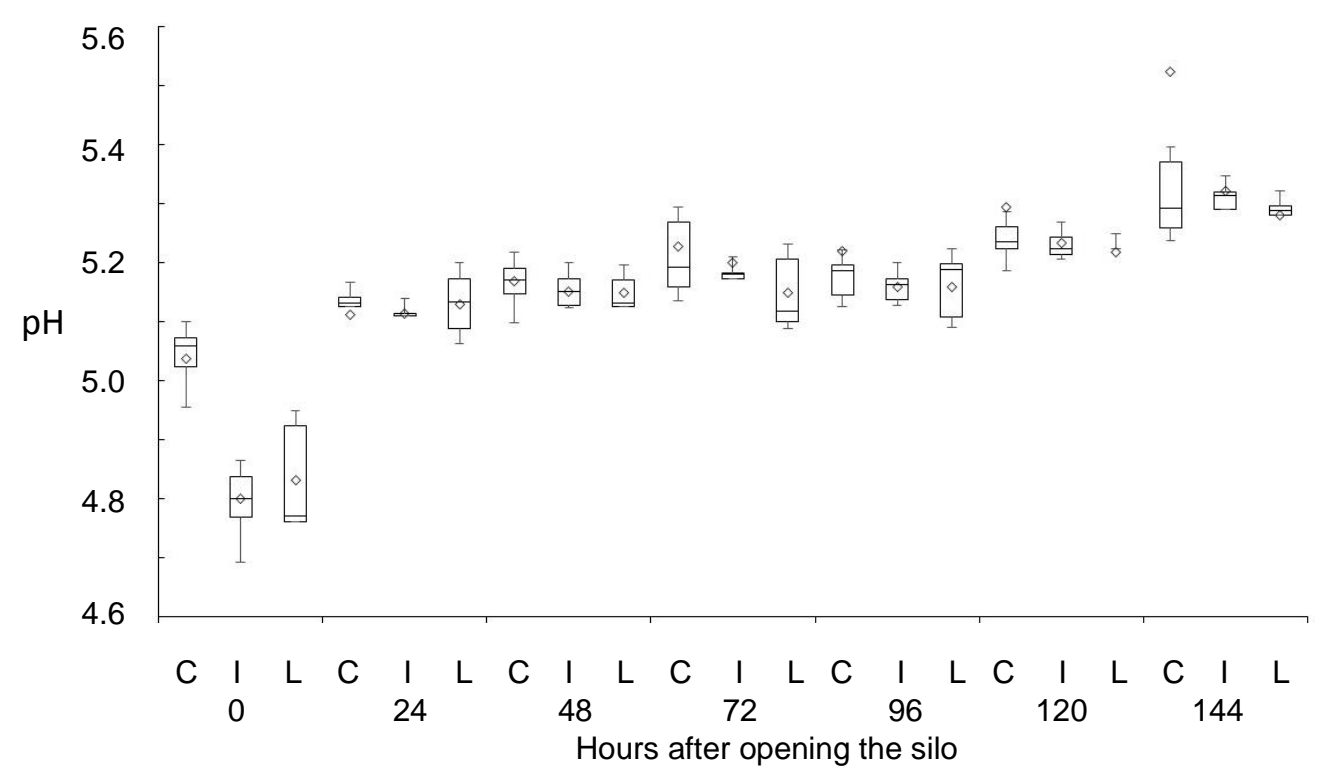

Figure $2 \mathrm{Mean} \mathrm{pH}$ values of the silages over the hours of aerobic exposure

C: silage treated with water, I: silage treated with Lactobacillus plantarum, Bacillus subtilis and Pediococcus Acidilactici, L: silage treated with Lactobacillus plantarum and Pediococcus pentosaceus 
The acetic acid production capacity of Bacillus subtilis led to the expectation that I would have higher aerobic stability. However, although the lower $\mathrm{pH}$ was seen initially, the effect dissipated within 24 hours of opening the silos and the difference between treatments in aerobic stability was not significant $(P>0.05)$ (Table 5).

Table 5 Values related to aerobic stability $( \pm S D)$ of Tanzania guinea grass silages with different microbial inoculants

\begin{tabular}{|c|c|c|c|c|}
\hline \multirow{2}{*}{ Variables } & \multicolumn{3}{|c|}{ Silages } & \multirow{2}{*}{$P$-value } \\
\hline & C & 1 & $\mathrm{~L}$ & \\
\hline Aerobic stability, hours & $115.2 \pm 9.60$ & $120.0 \pm 0.00$ & $110.4 \pm 11.15$ & 0.1889 \\
\hline Time for maximum temperature, hours & 144.0 & 144.0 & 144.0 & - \\
\hline $\mathrm{pH}$ after stability test, day 7 & $5.52^{\mathrm{a}} \pm 0.04$ & $5.32^{b} \pm 0.06$ & $5.28^{b} \pm 0.05$ & 0.0233 \\
\hline
\end{tabular}

C: silage treated with water, I: silage treated with Lactobacillus plantarum, Bacillus subtilis and Pediococcus acidilactici,

L: silage treated with Lactobacillus plantarum and Pediococcus pentosaceus

Although the regression models for temperature were different, the silages reached their maximum temperature at the same time. After seven days of evaluating aerobic stability, $\mathrm{pH}$ of $\mathrm{I}$ and $\mathrm{L}$ were significantly lower compared with C. Basso et al. (2012) reported mean pH values of 5.53 for corn silage inoculated with Bacillus subtilis and 6.73 for the control silage after 12 days of exposure to air. They suggested that this difference was due mainly to control of filamentous fungi, which otherwise became active from day 7 onwards. The present study ended on day 7 and thus this conclusion cannot be drawn. In agreement with Wilkinson and Davies (2012), success in controlling aerobic deterioration is not the result of a single intervention, and losses can be minimized at all stages of the ensiling process and during the time that the silage is being fed.

\section{Conclusions}

The inoculant containing Lactobacillus plantarum and Pediococcus pentosaceus was effective in controlling the level of $\mathrm{NH}_{3}-\mathrm{N}$ in Tanzania guinea grass silage. This inoculant and one containing Lactobacillus plantarum, Bacillus subtilis and Pediococcus acidilactici both reduced $\mathrm{pH}$, but the aerobic stability of the silages was affected by neither inoculant.

\section{Acknowledgements} reviews.

The authors wish to express their gratitude to Professors C.C. Jobim and M. Neumann for pre-submission

\section{Authors' Contributions}

FLMJ and DARM collected the data. VAPG and GJM developed the first draft of the article. EHH refined the manuscript. VHBJ designed the study, revised the manuscript, and analysed the data together with SG.

\section{Conflict of Interest Declaration}

There is no conflict of interest.

\section{References}

Adesogan, A.T., 2009. Challenges of tropical silage production. In: G.A. Broderick (ed.) Proceedings of the 15th International Silage Conference, Madison, Wisconsin, 2009. Pp. 139-154.

AOAC, 1995, Official methods of analytical chemists. 16th ed. Chapter 4: Animal feed. AOAC, Washington, DC.

Ávila, C.L.A., Pinto, J.C., Figueiredo, H.C.P., Morais, A.R., Pereira, O.G. \& Schwan, R.F., 2009. Estabilidade aeróbia de silagens de capim-mombaça tratadas com Lactobacillus buchneri. Rev. Bras. Zootecn. 38, 779-787.

Basso, F.C., Lara, E.C., Assis, F.B.D., Rabelo, C.H.S., Morelli, M. \& Reis, R.A., 2012. Características da fermentação e estabilidade aeróbia de silagens de milho inoculadas com Bacillus subtilis. Rev. Bras. Saúde Prod. Anim. 13, 1009-1019.

Bumbieris Junior, V.H., Guimarães, V.A.D.P., Fortaleza, A.P.D.S., Massaro Junior, F.L., Moraes, G.J.D. \& Meza, D.A.R., 2017. Aerobic stability in corn silage (Zea mays L.) ensiled with different microbial additives. Acta Sci Anim Sci. 39, 357-362. 
Cherney, J.H. \& Cherney, D.J.R., 2003. Assessing silage quality. In: D.R. Buxtou, R.E. Muck \& J.H. Harisson. Silage science and technology. Agronomy Monographs. Madison, Wisconsin, USA https://acsess.onlinelibrary.wiley.com/doi/abs/10.2134/agronmonogr42.c4

Dong, M., Li, Q., Xu, F., Wang, S., Chen, J., Li, W., 2020. Effects of microbial inoculants on the fermentation characteristics and microbial communities of sweet sorghum bagasse silage. Sci. Rep. 10, 1-9.

Downes, F.P. \& Ito, K., 2001. Compendium of methods for the microbiological examination of foods, 4th ed. American Public Health Association, Washington, DC. 107 pp.

Holzer, M., Mayrhuber, E., Danner, H. \& Braun, R., 2003. The role of Lactobacillus buchneri in forage preservation. Trends Biotechnol. 21, 282-287.

Khota, W., Pholsen, S., Higgs, D. \& Cai, Y., 2016. Natural lactic acid bacteria population of tropical grasses and their fermentation factor analysis of silage prepared with cellulase and inoculant. J. Dairy Sci. 99, 9768-9781.

Kleinschmit, D.H. \& Kung Junior, L., 2006. The effects of Lactobacillus buchneri 40788 and Pediococcus pentosaceus R1094 on the fermentation of corn silage. J. Dairy Sci. 89, 3999-4004.

Konca, Y., Beyzi, S.B., Ayaşan, T., Kaliber, M. \& Kiraz, A.B., 2016. The effects of freezing and supplementation of molasses and inoculants on chemical and nutritional composition of sunflower silage. Asian Australas. J. Ani. Sci. 29, 965-970.

Lammers, B.P., Buckmaster, D.R. \& Heinrichs, A.J. 1996. A simple method for the analysis of particle size of forage and total mixed rations. J. Dairy Sci. 79, 922-928.

McDonald, P., Henderson, A.R. \& Heron, S.J.E., 1991. The biochemistry of silage. 2nd ed. Chalcombe, Southampton, UK.

Muck, R.E., 2010. Silage microbiology and its control through additives. Rev. Bras. Zootech. 39, 183-191.

Muck, R.E., Nadeau, E.M.G., McAllister, T.A., Contreras-Govea, F.E., Santos, M.C. \& Kung, L., 2018. Silage review: Recent advances and future uses of silage additives. J. Dairy Sci. 101, 3980-4000.

Paziani, S.F., Nussio, L.G., Loures, R.S.D., Igarasi, S.M., Pedroso, A.F. \& Mari, L.J., 2006. Influência do teor de matéria seca e do inoculante bacteriano nas características físicas e químicas da silagem de capim Tanzânia. Acta Sci. Anim. Sci. 28, 265-271.

Santos, E.M., Pereira, O.G., Garcia, R., Ferreira, C.L.L.F., Oliveira, J.S. \& Silva, T.C., 2014. Effect of regrowth interval and a microbial inoculant on the fermentation profile and dry matter recovery of guinea grass silages. J. Dairy Sci. $97,4423-4432$.

Santos, E.M., Zanine, A.M., Ferreira, D.J., Oliveira, J.S., Penteado, D.C.S. \& Pereira, E.O.G., 2008. Inoculante ativado melhora a silagem de capim-tanzânia (Panicum maximum). Arch. Zootec. 57, 35-42.

Tabacco, E., Piano, S., Cavallarin, L., Bernardes, T.F. \& Borreani, G., 2009. Clostridia spore formation during aerobic deterioration of maize and sorghum silages as influenced by Lactobacillus buchneri and Lactobacillus plantarum inoculants. J. Appl. Microbiol. 107, 1632-1641.

Tomaz, P.K., Araujo, L.C., Sanches, L.A., Santos-Araujo, S.N., Lima, T.O., Lino, A.D.A. \& Ferreira, E.M., 2018. Effect of sward height on the fermentability coefficient and chemical composition of guinea grass silage. Grass Forage Sci. 73, 588-598.

Wilkinson, J.M. \& Davies, D.R., 2012. The aerobic stability of silage: Key findings and recent developments. Grass Forage Sci. 68, 1-19.

Zanine, A.M, Bonelli, E.A., Ferreira, D.J., Souza, A.L., Santos, E.M., Pinho, R.M. \& Parente, M.O., 2018. Fermentation and .chemical composition of guinea grass silage added with wheat meal and Streptococcus bovis. New Zeal. J. Agr Res. 61, 487-494.

Zanine, A.M., Bonelli, E.A., Souza, A.L., Ferreira, D.J., Santos, E.M., Ribeiro, M.D., Geron, L.J.V. \& Pinho, R.M.A., 2016. Effects of Streptococcus bovis isolated from bovine rumen on the fermentation characteristics and nutritive value of Tanzania grass silage. Sci. World J. 1-6. 